\title{
Selected clinical and therapeutic aspects of atopic and contact dermatitis
}

\section{Wybrane zagadnienia kliniczne i terapeutyczne dotyczące wyprysku atopowego i kontaktowego}

\author{
Krzysztof Kanabaj', Sara Shawkat', Aleksandra Kuźniak', Zygmunt Adamski', Dorota Jenerowicz² \\ 'Department of Dermatology, Poznan University of Medical Sciences, Poznan, Poland \\ 2Department of Allergic and Occupational Diseases of the Skin, Chair of Dermatology, Poznan University of Medical Sciences, Poznan, \\ Poland \\ 'Katedra i Klinika Dermatologii, Uniwersytet Medyczny, Poznań, Polska \\ 2Zakład Alergicznych i Zawodowych Chorób Skóry, Katedra Dermatologii, Uniwersytet Medyczny, Poznań, Polska \\ Dermatol Rev/Przegl Dermatol 2021, 108, 394-406 \\ DOI: https://doi.org/l0.5 | |4/dr.2021. I |3 I 57
}

\author{
CORRESPONDING AUTHOR/ \\ ADRES DO KORESPONDENCJI: \\ lek. Krzysztof Kanabaj \\ Katedra i Klinika \\ Dermatologii \\ Uniwersytet Medyczny \\ Poznań, Polska \\ tel.: +48 784055111 \\ e-mail: kkanabaj@gmail.com
}

\begin{abstract}
Atopic dermatitis and allergic contact dermatitis are two dermatoses associated with eczema and pruritus, accompanied by hypersensitivity reactions. However, the etiopathogenesis of these diseases is different, therefore also their diagnostic and therapeutic procedures vary. Atopic dermatitis, a skin-epidermal barrier defective disorder, is a more characteristic for children, although it also occurs in a small percentage of adults. Contact allergy, in which epidermal patch tests are the diagnostic tool, is diagnosed in children and in as many as $20 \%$ of adults. Atopic dermatitis and allergic contact dermatitis may coexist in the same patient. Etiologically different types of hand eczema often coexist. In addition, contact allergy may relate to substances used in the treatment of atopic dermatitis, such as emollients or, less frequently, antiseptics and glucocorticosteroids. For this reason, epidermal patch tests may be useful in this group of patients.
\end{abstract}

Key words: atopic dermatitis, allergic contact dermatitis, eczema.

\section{STRESZCZENIE}

Atopowe zapalenie skóry i alergiczny wyprysk kontaktowy to dwie dermatozy przebiegające $\mathrm{z}$ wypryskiem i świądem, którym towarzyszą reakcje nadwrażliwości. Etiopatogeneza tych chorób jest jednak odmienna, dlatego różnią się one postępowaniem diagnostyczno-leczniczym. Atopowe zapalenie skóry, choroba z kręgu atopii z defektem bariery skórno-naskórkowej, rozpoznawana na podstawie kryteriów Hanifina i Rajki, jest jednostką bardziej charakterystyczną dla dzieci, chociaż również występuje u niewielkiego odsetka osób dorosłych. Alergia kontaktowa, w której narzędzie diagnostyczne stanowią naskórkowe testy płatkowe, jest rozpoznawana u dzieci i aż u 20\% dorosłych. Atopowe zapalenie skóry i alergiczny wyprysk kontaktowy mogą współwystępować u tego samego pacjenta; często stwierdza się współistnienie różnych etiologicznie odmian wyprysku rąk. Ponadto alergia kontaktowa może dotyczyć substancji wykorzystywanych w leczeniu atopowego zapalenia skóry, takich jak emolienty lub rzadziej środki antyseptyczne i glikokortykosteroidy. $Z$ tego powodu naskórkowe testy płatkowe mogą być przydatne w tej grupie chorych. 
Słowa kluczowe: atopowe zapalenie skóry, alergiczny wyprysk kontaktowy, wyprysk.

\section{INTRODUCTION}

Atopic dermatitis (AD) and allergic contact dermatitis (ACD) are inflammatory skin conditions that cause inflammation of the skin and itching. Although the clinical presentation is similar, and both diseases are associated with hypersensitivity reactions, their mechanism of formation and triggering factors are different, which is important both in diagnostic and therapy. Currently, the frequency of occurrence of contact allergy in people with AD compared to the general population, as well as the percentage in individual age groups are subject to numerous analyzes. An important issue is the interference of immunological phenomena in the course of $\mathrm{AD}$ and allergic contact dermatitis. In people with AD, it is reasonable to perform patch tests (PT), with particular emphasis on substances used in the treatment of this dermatosis [1, 2].

\section{HISTORICAL OUTLINE}

The first reports of disease symptoms corresponding to AD appeared in antiquity during the reign of Emperor Octavian August [3, 4]. The concept of atopy comes from Ancient Greek (Атопіа), and was introduced by Coca and Cooke in 1923, while the concept of AD was proposed by Salzburger and Weiss in 1933 [2-4]. Other terms used for the disease include: atopic eczema, endogenous eczema, scabies, neurodermatitis atopica, atopic eczema dermatitis atopica [4]. In 1980, Hanifin and Rajka developed the diagnostic criteria that are still used today. They are divided into two groups: major and minor criteria [5, 6].

Contact dermatitis was first described by Bateman in 1817, who described the disease as an intolerance to certain substances as a result of contact with the skin. Modern standards of diagnostics began in 1910, when Block introduced the first method of performing patch tests [7].

\section{ETIOPATHOGENESIS}

Unlike other atopy disorders, AD symptoms do not show a tendency for a rapid remission upon disappearance of an allergen; symptoms tend to persist for a long time, and the eruptions shows features of a delayed type hypersensitivity reaction, as the pathomechanism involves immunological factors

\section{WPROWADZENIE}

Atopowe zapalenie skóry (atopic dermatitis - AD) i alergiczny wyprysk kontaktowy (allergic contact dermatitis - ACD) to zapalne choroby skóry, w przebiegu których występuje stan zapalny skóry i świąd. Mimo że obraz kliniczny jest podobny, a obu jednostkom chorobowym towarzyszą reakcje nadwrażliwości, ich mechanizm powstawania oraz czynniki wywołujące są różne, co ma znaczenie w postępowaniu zarówno diagnostycznym, jak i leczniczym. Obecnie częstość występowania ACD u osób z AD w porównaniu z częstością w populacji ogólnej, a także odsetek w poszczególnych grupach wiekowych podlega licznym analizom. Ważnym zagadnieniem jest interferencja zjawisk immunologicznych w przebiegu AD i ACD. U osób z AD zasadne jest wykonywanie testów płatkowych (patch test - PT), ze szczególnym uwzględnieniem substancji używanych w leczeniu tej dermatozy $[1,2]$.

\section{RYS HISTORYCZNY}

Pierwsze doniesienia o objawach chorobowych odpowiadających AD pojawiły się już w starożytności za czasów cesarza Oktawiana Augusta [3, 4]. Pojęcie atopii wywodzi się z języka starogreckiego (atonia) i zostało wprowadzone przez Coca i Cooke'a w 1923 roku, natomiast określenie atopowe zapalenie skóry zostało zaproponowane przez Salzburgera i Weissa w 1933 roku [2-4]. Do innych określeń opisujących chorobę należą: wyprysk atopowy, wyprysk endogenny, świerzbiączka, neurodermitis atopica, atopic eczema, dermatitis atopica [4]. W 1980 roku Hanifin i Rajka opracowali stosowane do dzisiaj kryteria rozpoznawcze, które podzielili na dwie grupy: kryteria większe i mniejsze [5, 6].

Wyprysk kontaktowy był po raz pierwszy opisany przez Batemana w 1817 roku, który przedstawił tę jednostkę chorobową jako nietolerancję pewnych substancji w wyniku ich kontaktu ze skórą. Współczesne standardy diagnostyki zostały zapoczątkowane w 1910 roku, kiedy to Block przedstawił pierwszy sposób wykonywania testów płatkowych [7].

\section{ETIOPATOGENEZA}

W odróżnieniu od innych chorób z kręgu atopii, objawy w przebiegu AD nie mają tendencji do szybkiej remisji wskutek eliminacji uczulającego alergenu. 
in the course of I and IV allergic reactions as well as non-allergic factors. Understanding the chronic nature of skin lesions in AD enabled Bruijnzeel-Coomen to discover high affinity IgE receptors (FceRI), being a factor in the development of IgE-dependent eczema $[1,2]$. The main antigens involved in the immune response are air-derived and food macromolecular protein antigens. Within the epidermis, they bind to antigen-specific IgE on Langerhans cells via FceRI. The IgE-allergen complex is presented to T lymphocytes in lymph nodes, as a result of which specifically sensitized CD4+ Th2 lymphocytes differentiate and multiply. After penetrating the skin, Th2 lymphocytes induce an increase in "type 2 " cytokines (IL-4, IL-5, IL-13), which are the main inflammatory mediators in AD. These cytokines have a multidirectional action. Among others, they stimulate B lymphocytes to produce antigen-specific IgE, stimulate mast cell degranulation, and activate CD8+ Tc $[1,2,8]$.

Characteristic for $\mathrm{AD}$ is a genetic defect in the skin-epidermal barrier. Mutations within the group of epidermal differentiation complex (EDC) genes encoding proteins responsible for the final process of keratinocyte differentiation, the most important of which is filaggrin, significantly disturb the structure and function of the dermal-epidermal barrier [8]. Disorders of filaggrin metabolism reduce the amount of natural moisturizing factor and, through reduced production of trans-urocaine (t-UCA), and increase skin $\mathrm{pH}[2,8]$. These changes may result in increased permeability of the epidermis to contact allergens. Excessive activity of serine proteases, related to a disturbed balance between their activators and inhibitors, causes a reduction in the thickness of the stratum corneum and abnormal ceramide synthesis $[1,2,8,9]$. Degradation of extracellular lipid processing enzymes ( $\beta$-glucocerebrosidase, acid sphingomyelinase) and reduction of lamellar body secretion via the protease activated receptor 2 (PAR2) causes abnormalities in the lipid coat $[1,2,8,10]$. Structural defect of the dermal-epidermal barrier may lead to penetration of haptens of various lipophilicity and of substances with a molecular weight above $500 \mathrm{Da}$ [1].

The formation of ACD is related to the $4^{\text {th }}$ reaction according to the Coombs classification. Substances such as metals, rubber, resins, some drugs or fragrances are haptens which, when combined with proteins, become antigens and cause sensitization of the body during the induction phase. Manifestation of the full-blown phase is eczema that appears as a result of direct contact with an allergen to which the person has previously developed hypersensitivity $[2,10]$. An induction phase takes place in a regional lymph node, during which Langerhans cells present the antigen to T lymphocytes. This reaction is stimulated by various cytokines (including IL-1, IL-2, TNF) $[1,11]$.
Utrzymują się one długotrwale, a obraz zmian ma cechy reakcji nadwrażliwości typu opóźnionego, gdyż $\mathrm{w}$ patomechanizmie biorą udział czynniki immunologiczne w przebiegu I i IV reakcji alergicznej oraz czynniki niealergiczne. Zrozumienie przewlekłego charakteru zmian skórnych w przebiegu AD umożliwiło odkrycie przez Bruijnzeel-Coomen receptorów dla immunoglobuliny IgE o wysokim powinowactwie (Fc\&RI), co jest czynnikiem powstania wyprysku IgE-zależnego [1, 2]. Do głównych antygenów biorących udział w odpowiedzi immunologicznej należą powietrznopochodne oraz pokarmowe wielkocząsteczkowe antygeny białkowe. W obrębie naskórka łączą się one z antygenowo swoistymi IgE obecnymi na komórkach Langerhansa za pośrednictwem FceRI. Kompleks IgE-alergen prezentowany jest limfocytom T w węźle chłonnym, w wyniku czego dochodzi do zróżnicowania i namnożenia swoiście uczulonych CD4+ limfocytów Th2. Limfocyty Th2 po przeniknięciu do skóry wywołują wzrost cytokin "typu 2" [interleukina (IL) 4 (IL-4), IL-5, IL-13], będących głównymi mediatorami procesu zapalnego w przebiegu AD. Cytokiny te mają wielokierunkowe działanie, m.in. stymulują limfocyty B do wytwarzania antygenowo swoistych IgE, pobudzają degranulację mastocytów oraz aktywują CD8+ Tc $[1,2,8]$.

Dla AD charakterystyczny jest defekt genetyczny bariery skórno-naskórkowej. Mutacje w obrębie grupy genów kompleksu różnicowania naskórka (epidermal differentiation complex - EDC) kodujących białka odpowiedzialne za końcowy proces różnicowania keratynocytów, z których najważniejsza jest filagryna, istotnie zaburzają strukturę i funkcję bariery skórno-naskórkowej [8]. Zaburzenia przemiany filagryny obniżają ilość naturalnego czynnika nawilżającego oraz powodują wzrost pH skóry poprzez zmniejszone wytwarzanie kwasu trans-urokainowego (t-UCA) $[2,8]$. Zmiany te mogą skutkować zwiększoną przepuszczalnością naskórka dla alergenów kontaktowych. Nadmierna aktywność proteaz serynowych, związana z zaburzoną równowagą między ich aktywatorami i inhibitorami, skutkuje zmniejszeniem grubości warstwy rogowej oraz nieprawidłową syntezę ceramidów [1, 2, 8, 9]. Degradacja zewnątrzkomórkowych enzymów przetwarzających tłuszczowce ( $\beta$-glukocerebrozydazy, kwaśnej sfingomielinazy) oraz zmniejszenie wydzielania ciałek lamelarnych za pośrednictwem receptora aktywowanego proteinazą typu 2 (protease activated receptor 2 - PAR2) powoduje nieprawidłowości w obrębie płaszcza lipidowego $[1,2,8,10]$. Defekt strukturalny bariery skórno-naskórkowej może prowadzić do przenikania haptenów różniących się lipofilnością oraz substancji o masie cząsteczkowej powyżej 500 Da [1].

Powstawanie ACD wiąże się z reakcją IV wg klasyfikacji Coombsa. Substancje, takie jak metale, guma, żywice, niektóre leki czy mieszanki zapachowe, są haptena- 
Then, upon re-exposure to the antigen, the symptomatic phase begins, where specifically activated memory $\mathrm{T}$ cells initiate the inflammatory process. Keratinocytes are also activated and participate in antigen presentation via MHC class II molecules. Memory Th1 lymphocytes and Tc (cytotoxic) lymphocytes are mainly involved in this process [2]. Cytokines conventionally referred to as "type 1 " which are of importance in ACD are: IFN, IL-2 and IL-12. Acute and chronic forms of ACD have been clinically distinguished $[1,11]$.

Contact dermatitis also occurs in a non-allergic form caused by irritation.

\section{ATOPIC DERMATITIS AND ALLERGIC CONTACT DERMATITIS - EPIDEMIOLOGY}

$\mathrm{AD}$ affects up to $25 \%$ of children and $2-3 \%$ of adults; in the first years of life, the prevalence of this disease in both sexes is similar, but after the age of 6 , a predominance of the female sex $(3: 2)$ is observed $[12,13]$.

The vast majority of AD tends to resolve by age 5 , while 1 in 5 patients will develop symptoms in adulthood. The first onset of the disease may also appear de novo in adulthood - it affects up to $25 \%$ of this group of patients. Prevalence of the disease is more noticeable in urban areas [14].

$\mathrm{ACD}$ is a more common disease than AD. Reviews show that up to $20 \%$ of the adult population in Europe can develop symptoms of contact allergy to at least one allergen [15].

It is also worth noting that the phenomenon of contact allergy is not at all uncommon in children. Its frequency in the examined healthy children is 13.3$24.5 \%$, while in the population of children presenting lesions of eczema morphology, contact allergy is found in $35.3-66 \%$ of this population. The most common contact sensitizer is nickel sulphate $[1,2,16,17]$.

While ACD was previously thought to be less common in AD patients due to decreased lymphocyte-mediated hypersensitivity, more recent studies show that its incidence in children with $\mathrm{AD}$ is similar to or greater than that in healthy children. There were statistically significant differences in the frequency of contact allergy in children with $\mathrm{AD}$ in various age groups. The highest incidence was recorded in children under 3 years of age. Certain types of contact allergy, such as hand eczema or composite allergy, are more common in atopy patients $[1,17]$.

In $\mathrm{AD}$, there is an altered skin microbiome. Due to disorders in the immune system, a greater susceptibility to the development of bacterial, fungal and viral infections is observed [17]. Patients with AD show cutaneous hypersensitivity to allergens, but their mi, które w połączeniu z białkami stają się antygenami i powodują $\mathrm{w}$ fazie indukcji uczulenie organizmu. Manifestacją fazy pełnoobjawowej jest wyprysk pojawiający się na skutek bezpośredniego kontaktu $\mathrm{z}$ alergenem, na który wcześniej osoba wytworzyła nadwrażliwość [2, 10]. W regionalnym węźle chłonnym zachodzi faza indukcji, podczas której komórki Langerhansa prezentują antygen limfocytom T. Reakcja ta pobudzana jest przez różne cytokiny (m.in. IL-1, IL-2, TNF) [1, 11].

Następnie, podczas ponownej ekspozycji na antygen, dochodzi do fazy ujawnienia, kiedy to swoiście aktywowane limfocyty T pamięci inicjują proces zapalny. Aktywacji ulegają również keratynocyty, które za pośrednictwem cząsteczek MHC klasy II uczestniczą $\mathrm{w}$ prezentacji antygenu. $\mathrm{W}$ proces ten zaangażowane są przede wszystkim limfocyty Th1 pamięci oraz Tc (cytotoksyczne) [2]. Cytokiny, tradycyjnie nazywane "typu 1", które mają znaczenie w ACD, to: interferon (IFN), IL-2 i IL-12. Klinicznie wyróżniono postać ostrą i przewlekłą ACD $[1,11]$.

Wyprysk kontaktowy występuje również w postaci niealergicznej wywoływanej przez podrażnienie.

\section{ATOPOWE ZAPALENIE SKÓRY I ALERGICZNY WYPRYSK KONTAKTOWY - EPIDEMIOLOGIA}

AD dotyczy do 25\% dzieci i 2-3\% dorosłych; w pierwszych latach życia częstość występowania tej choroby u obu płci jest podobna, natomiast po 6. roku życia można stwierdzić przewagę płci żeńskiej $(3$ : 2) $[12,13]$.

W większości AD ma tendencję do ustępowania przed 5. rokiem życia, natomiast 1 na 5 pacjentów będzie miał objawy w dorosłym życiu. Pierwszy rzut choroby może się pojawić również de novo w okresie dorosłości - dotyczy to nawet $25 \%$ tej grupy chorych. Prewalencja choroby jest większa w obszarach miejskich [14].

ACD jest częstszym schorzeniem niż AD; przeglądy dowodzą, że aż u 20\% dorosłej populacji w Europie można stwierdzić objawy alergii kontaktowej na co najmniej jeden alergen [15].

Warto również zauważyć, że zjawisko alergii kontaktowej wcale nie jest rzadkie u dzieci. Jego częstość u badanych zdrowych dzieci wynosi 13,3-24,5\%, natomiast spośród dzieci ze zmianami o morfologii wyprysku u 35,3-66\% stwierdza się alergię kontaktową. Najczęstszą substancją uczulającą kontaktowo jest siarczan niklu $[1,2,16,17]$.

Mimo że wcześniej uważano, że alergiczne kontaktowe zapalenie skóry występuje rzadziej u pacjentów z AD ze względu na zmniejszoną nadwrażliwość za pośrednictwem limfocytów, nowsze badania pokazują, że jego częstość u dzieci z AD jest podobna lub większa od częstości w grupie dzieci zdrowych. Stwierdzono statystycznie istotne różnice w częstości alergii kontaktowej u dzieci chorych na $\mathrm{AD}$ w poszczególnych grupach wie- 
epidermal barrier dysfunction facilitates penetration of foreign antigens. Studies with PT in a European cross-sectional population have shown that loss of filaggrin mutations in AD increase the risk of contact sensitization only with nickel [1].

\section{SYMPTOMS}

Pruritus is the most common symptom of AD [6] Typical locations include elbow and knee bends, the skin of the face and neck $[1,2]$. Atopy in a patient or in a family history may manifest as bronchial asthma, $\mathrm{AD}$, hay fever, urticaria, allergic conjunctivitis and certain food intolerances, and is characterized by an immediate mechanism of hypersensitivity [18-20]. There is an overproduction of $\operatorname{IgE}$ in response to airborne and food allergens. Genetic tendencies play a significant role in the development of atopy $[1,2$, 18-20].

In $\mathrm{AD}$ in adult patients, lesions are located on the face and neck, and a significant proportion of patients (approximately 30\%) develop atopic hand eczema. In young and older children (over 2 years of age), eczema lesions tend to change location, often limited to elbow and knee bends, as well as wrists and ankles, although they can occur anywhere [19]. According to Bieber's division, in infants and younger children (from 3 months to 2 years of age) typical locations of lesions are: the cheeks, scalp, neck, upright surfaces of the limbs and the torso. Changes in the area of the scalp can cause symptoms of the so-called cradle cap, which is mistakenly associated with seborrheic dermatitis [20].

Contrary to $\mathrm{AD}$, changes in the course of ACD are most often located on the dorsal and palmar surfaces of hands $(88.9 \%)$ and on the face $(36.8 \%)$, with the sole location on the face in $10.3 \%$ of patients [21]. In $83.3 \%$ of cases, lesions are located on the pads of three fingers: thumbs, index and ring fingers [21]. Eczema lesions can also be found on the auricle, neck, forearms, sacrum, buttocks, thighs, dorsal surface of the feet or other areas [21-25].

\section{DERMATOLOGICAL DISEASES ASSOCIATED WITH ATOPIC DERMATITIS}

The complex pathogenesis of AD, including both dermal-epidermal barrier dysfunction, immunological abnormalities, and changes in the skin microbiome, leads to the association of this dermatosis with other similar diseases. The skin barrier defect may be important in white dandruff (pityriasis alba), because of the mutation in the filaggrin gene, it is associated with the formation of ichthyosis vulgaris and keratosis pilaris [26-29]. A skin barrier defect kowych. Największą częstość zanotowano u dzieci poniżej 3. roku życia. Pewne rodzaje alergii kontaktowej, takie jak wyprysk rąk lub alergia na kompozyty, są częstsze u pacjentów $\mathrm{z}$ atopią $[1,17]$.

W przebiegu AD mamy do czynienia ze zmienionym mikrobiomem skóry. Ze względu na zaburzenia w układzie immunologicznym obserwuje się zwiększoną podatność na rozwój infekcji bakteryjnych, grzybiczych i wirusowych [17]. Chorzy na AD wykazują skórną nadwrażliwość na alergeny, jednak występująca u nich dysfunkcja bariery naskórkowej ułatwia przenikanie obcych antygenów. Badania z użyciem PT w europejskiej populacji przekrojowej pokazały, że mutacje skutkujące utratą funkcji filagryny, występujące w przypadku AD, zwiększają ryzyko uczulenia kontaktowego wyłącznie w przypadku niklu [1].

\section{OBJAWY}

Świąd jest najczęstszym objawem AD [6]. Typowe umiejscowienie oznacza zgięcia łokciowe i kolanowe, skórę twarzy i szyi [1,2]. Atopia u chorego lub w wywiadzie rodzinnym może ujawniać się w postaci astmy oskrzelowej, AD, kataru siennego, pokrzywki, alergicznego zapalenia spojówek i niektórych nietolerancji pokarmowych, a charakteryzuje ją natychmiastowy mechanizm nadwrażliwości [18-20]. Dochodzi tu do nadmiernego wytwarzania IgE w odpowiedzi na alergeny powietrznopochodne i pokarmowe. Znaczącą rolę w rozwoju atopii odgrywają skłonności genetyczne $[1,2,18-20]$.

W AD skóry u pacjentów dorosłych zmiany lokalizują się na twarzy i szyi, a u znacznej części pacjentów (około 30\%) występuje atopowy wyprysk rąk. U małych i starszych dzieci (po 2. roku życia) zmiany wypryskowe mają tendencję do zmiany lokalizacji, często ograniczają się do zgięć łokciowych i kolanowych, a także nadgarstków i skóry nad stawami skokowymi, chociaż mogą wystąpić w dowolnym miejscu [19]. Według podziału Biebera u niemowląt i dzieci młodszych (od 3. miesiąca życia do 2. roku życia) typowymi lokalizacjami zmian są policzki, skóra owłosiona głowy, szyja, wyprostne powierzchnie kończyn oraz tułów. Zmiany zajmujące skórę owłosioną głowy mogą spowodować objawy tzw. ciemieniuchy, która jest błędnie kojarzona z łojotokowym zapaleniem skóry [20].

W odróżnieniu od AD, zmiany w przebiegu ACD lokalizują się najczęściej na powierzchni grzbietowej i dłoniowej rąk $(88,9 \%)$ oraz na twarzy $(36,8 \%)$, z jedyną lokalizacją na twarzy wśród 10,3\% pacjentów [21]. W 83,3\% przypadków zmiany są umiejscowione na opuszkach trzech palców rąk: pierwszego, drugiego i czwartego [21]. Zmiany wypryskowe mogą pojawiać się również na małżowinie usznej, szyi, przedramionach, w okolicy krzyżowej, pośladkowej, na udach, powierzchni grzbietowej stóp lub w innej okolicy [21-25]. 
along with an abnormal immune response occurs in contact eczema. It can take the form of allergic contact eczema or irritative contact eczema. The relationship between $\mathrm{AD}$ and hand dermatitis (HD) is well known, for which AD is the single most important risk factor, although exposure to irritants is the most common cause of HD at work [30-32]. It has been shown that patients with a proven tendency to AD are more likely to develop occupational irritant hand dermatitis (OIHD) $[33,34]$. AD affects the frequency and course of skin infections, both bacterial - impetigo, viral - herpetic eczema (eczema herpeticum), and fungal - (Malassezia spp., Candida spp., Dermatophytes) [35-37]. An abnormal immune response may be an element of the etiopathogenesis of autoimmune skin diseases such as alopecia areata and vitiligo [37].

\section{DIAGNOSTICS OF ATOPIC DERMATITIS}

The diagnosis of AD takes into account the presence of specific clinical symptoms and results of additional investigations. One of the first, most significant and most widely used criteria for the diagnosis of AD was proposed in 1980 by Hanifin and Rajka. Modification of these criteria was proposed in 2003 at the conference of the American Academy of Dermatology [26] (they were updated many times, most recently in 2013), where symptoms were divided into major, important and additional. The British Working Group diagnostic criteria also apply to epidemiological and population studies [38]. They include one mandatory criterion which is pruritus of the skin and 5 others, relating to skin lesions, dryness, presence of asthma, allergic rhinitis and early onset of symptoms. The original version of these criteria should not be used in young children but some amendments have been proposed. Other diagnostic criteria were also proposed by Kang and Tian or the International Study of Asthma and Allergies in Childhood (ISAAC) [39, 40].

Additional tests performed include prick tests with food and airborne allergens and determination of total and antigen-specific IgE levels in the blood serum. These are non-specific tests, as over $20 \%$ of patients have normal IgE levels, but their very high levels may correlate with more severe and chronic disease. In AD, there is an elevated level of mast cells and eosinophils, which, due to the presence in other diseases, is characterized by low specificity. Diagnostic role of the following biomarkers is being investigated: new subclasses of T-lymphocytes, cytokines, chemokines, CD30 molecules, macrophagederived chemoattractant (MCD), IL-12, IL-16, IL-18, IL-31 and thymic chemokine (TARC) [41].

\section{CHOROBY SKÓRY ZWIAZZANE Z ATOPOWYM ZAPALENIEM SKÓRY}

Złożona patogeneza AD, obejmująca zarówno dysfunkcję bariery skórno-naskórkowej, nieprawidłowości immunologiczne oraz zmiany mikrobiomu skóry, prowadzi do związku tej dermatozy z innymi chorobami powstającymi na podobnym tle. Defekt bariery skórnej może mieć znaczenie w łupieżu białym, z powodu mutacji genu filagryny ma związek z powstawaniem rybiej łuski i rogowacenia mieszkowego [26-29]. Defekt bariery skórnej wraz z nieprawidłową odpowiedzią immunologiczną mają miejsce w przypadku wyprysku kontaktowego. Może mieć on formę wyprysku kontaktowego alergicznego lub wyprysku kontaktowego z podrażnienia. Bardzo dobrze znany jest związek AD z wypryskiem rąk (hand dermatitis - HD), dla którego AD jest najważniejszym pojedynczym czynnikiem ryzyka, choć najczęstszą przyczyną HD w pracy jest narażenie na czynniki drażniące [30-32]. Wykazano, że pacjenci z udowodnioną tendencją do AD są bardziej narażeni na rozwój zawodowego wyprysku rąk z podrażnienia (occupational irritant hand dermatitis - OIHD) [33, 34]. AD ma wpływ na częstość i przebieg infekcji skórnych, zarówno bakteryjnych - liszajec, wirusowych - wyprysk opryszczkowy, jak i grzybiczych spowodowanych przez: Malassezia spp., Candida spp., dermatofity [35-37]. Nieprawidłowa odpowiedź immunologiczna może być elementem etiopatogenezy autoimmunologicznych chorób skórnych, takich jak łysienie plackowate i bielactwo [37].

\section{DIAGNOSTYKA ATOPOWEGO ZAPALENIA SKÓRY}

W diagnostyce AD bierze się pod uwagę obecność określonych objawów klinicznych oraz wyniki badań dodatkowych. Jedne z pierwszych, najbardziej znaczących i najszerzej stosowanych do dzisiaj kryteriów rozpoznania AD zaproponowali w 1980 roku Hanifin i Rajka. Modyfikację tych kryteriów zaproponowano w 2003 roku podczas konferencji American Academy of Dermatology [26] (były one wielokrotnie uaktualniane, ostatnio w 2013 roku), gdzie objawy podzielono na główne, ważne i dodatkowe. $W$ badaniach epidemiologicznych i populacyjnych zastosowanie mają również kryteria diagnostyczne Brytyjskiej Grupy Roboczej [38]. Obejmują one jedno obowiązkowe kryterium, którym jest świąd skóry, i 5 innych, dotyczących zmian skórnych, suchości, obecności astmy, alergicznego nieżytu nosa oraz wczesnego początku objawów. Pierwotnej wersji tych kryteriów nie powinno się stosować u małych dzieci, ale zaproponowano co do tego poprawki. Inne kryteria diagnostyczne zaproponowali również Kang i Tian oraz International Study of Asthma and Allergies in Childhood (ISAAC) [39, 40]. 


\section{DIAGNOSTICS OF ALLERGIC CONTACT DERMATITIS}

PT are used in the diagnosis of ACD. Considering the possibility of contact allergy also in AD patients, it is reasonable to perform PT in them. Severity of AD may have an impact on the PT score. Positive PT results may be more frequent in younger patients. In AD patients, agents used in the treatment of this dermatosis should be included in PT. Emollients should be especially considered when testing personal products. Fortunately, topical antiseptics and corticosteroids rarely give a positive reaction in PT $[1,2]$.

\section{METHODS OF ASSESSMENT OF SEVERITY OF ATOPIC DERMATITIS}

Assessing the severity of AD is important for selecting an appropriate therapy and for monitoring of treatment effectiveness. For this purpose, more than 20 measurement scales have been developed. The most commonly used is the SCORAD (scoring atopic dermatitis) scale, where both objective symptoms (the extent and intensity of skin lesions) and subjective symptoms (pruritus and sleep disturbances) are assessed. A variant of this scale, oSCORAD (objective SCORAD), was also created, in which subjective symptoms are not taken into account, as they correlate less with the extent and intensity of skin lesions. Symptoms of this kind are also not taken into account in the second most frequently used scale - EASI (Eczema Area and Severity Index). POEM (Patientoriented Eczema Measure) is an important scale that takes into account subjective symptoms that have occurred according to the patient's report during the previous week, such as itching, sleep disturbances, bleeding, oozing, skin cracks, peeling and dry skin. It correlates well with the DLQI (Dermatology Life Quality Index) and CDLQI (Children's Dermatology Life Quality Index) scales assessing the quality of life. EASI and POEM scales are recommended by the HOME group for use in clinical trials in order to standardize the methods of measuring the severity of $\mathrm{AD}[42,43]$.

\section{TREATMENT}

In both cases, the therapeutic management depends on severity of the disease. It is essential to avoid allergens and irritants, which is especially important in ACD. If this is not possible, appropriate procedures should be implemented. Treatment of both AD and ACD should be modified depending on the phase of the disease $[2,41]$.
Wykonywane badania dodatkowe obejmują testy punktowe $\mathrm{z}$ alergenami pokarmowymi i powietrznopochodnymi oraz oznaczenie stężenia całkowitych oraz antygenowo swoistych IgE w surowicy. Są to testy niespecyficzne, gdyż ponad $20 \%$ chorych ma prawidłowe stężenia IgE, jednak bardzo wysokie stężenie może korelować z cięższym i przewlekłym przebiegiem choroby. W AD stwierdza się podwyższony poziom mastocytów i eozynofilów, co ze względu na występowanie w innych jednostkach chorobowych cechuje się niską swoistością. Badana jest rola diagnostyczna następujących biomarkerów: nowych podklas limfocytów T, cytokin, hemokin, cząsteczki CD30, chemoatraktantu pochodzącego z makrofagów (MCD), IL-12, IL-16, IL-18, IL-31 i chemokiny grasiczej (TARC) [41].

\section{DIAGNOSTYKA ALERGICZNEGO WYPRYSKU KONTAKTOWEGO}

W diagnostyce ACD stosuje się PT. Z uwagi na możliwość wystąpienia alergii kontaktowej także u pacjentów z AD, zasadne jest wykonywanie u nich PT. Nasilenie AD może mieć wpływ na wynik testów. U młodszych pacjentów dodatnie wyniki mogą się okazać częstsze. U pacjentów z AD należy uwzględnić $\mathrm{w}$ testach środki stosowane $\mathrm{w}$ terapii tej dermatozy. Testując produkty osobiste, należy szczególnie uwzględnić emolienty. Miejscowe środki antyseptyczne i glikokortykosteroidy rzadko dają dodatnie wyniki PT [1, 2].

\section{METODY OCENY NASILENIA ATOPOWEGO ZAPALENIA SKÓRY}

Ocena stopnia nasilenia AD jest istotna dla wyboru odpowiedniej terapii oraz monitorowania skuteczności leczenia. W tym celu powstało ponad 20 skal pomiarowych. Najczęściej stosowana jest skala SCORAD (scoring atopic dermatitis), w której ocenie podlegają zarówno objawy obiektywne (rozległość i nasilenie zmian skórnych), jak i subiektywne (świąd i zaburzenia snu). Utworzono również wariant tej skali, oSCORAD (objective SCORAD), w którym nie uwzględnia się objawów subiektywnych, gdyż korelują one słabiej z rozległością i nasileniem zmian skórnych. Tego rodzaju objawy nie są również brane pod uwagę w drugiej co do częstości stosowania skali - EASI (Eczema Area and Severity Index). Istotną skalą, która uwzględnia objawy subiektywne występujące według pacjenta w czasie poprzedniego tygodnia, takie jak świąd, zaburzenia snu, krwawienie, sączenie, pęknięcia skóry, łuszczenie i suchość skóry, jest POEM (Patient-oriented Eczema Measure). Dobrze koreluje ona ze skalami DLQI (Dermatology Life Quality Index), i CDLQI (Children's Dermatology Life Quality Index) oceniającymi jakość życia. Ska- 


\section{Topical treatment}

Comprehensive emollient therapy aims to restore and repair the impaired function of the epidermal barrier in AD. Emollients are used both in the active phase of the disease and in the period of remission. They are used to moisturize the skin, restore tightness of the stratum corneum, reduce itching and inhibit the penetration of haptens. It is important to apply them frequently to the skin (at least 2-3 times a day, $250-500 \mathrm{~g} /$ week). Emollients should not be applied directly to the skin affected by active inflammation - in this case, anti-inflammatory drugs should be applied first - topical glucocorticosteroids (tGCS) and topical calcineurin inhibitors ( $\mathrm{tCI}$ [41]. Although the role of emollients in ACD is not as crucial as in AD, it should be noted that it is worth adding them to the standard procedure. In $\mathrm{ACD}$, softeners, moisturizers, or barrier creams can be used as secondary prevention against irritation [2].

Apart from emollients, the mainstay of treatment are tGCS, which have been divided into groups based on their potency. It should be mentioned that the potency of tGCS depends on their concentration and form [41]. In the chronic phase of AD, tGCS ointments or creams containing $5-10 \%$ urea and/or $5-10 \%$ salicylic acid are recommended. Glucocorticosteroids, in addition to their anti-inflammatory, antiproliferative and immunosuppressive properties, have an antipruritic effect. Good penetration into the skin is also associated with the occurrence of adverse effects. They are also used as first-line treatment of ACD. Medium to high-potency topical steroids (e.g., $0.1 \%$ triamcinolone or $0.05 \%$ clobetasol) are used to treat acute localized lesions, while in areas with thinner skin (e.g., folds, eyelids, facial skin, anal and genital areas), it is reasonable to use less powerful steroids, e.g. cream with desesonide, in order to minimize the risk of atrophy. When skin lesions cover a significant (> 20\%) body surface area, the use of systemic GCS should be considered. It is recommended to administer prednisone for 5-7 days at a dose of $0.5-1 \mathrm{mg} / \mathrm{kg}$ body weight daily then gradually tapering the dose down, to discontinuation $[1,2]$.

Another commonly used drugs are tCI. It is a group of drugs devoid of adverse effects associated with the use of tGCS. These preparations are drugs with documented anti-inflammatory and anti-allergic properties. Pimecrolimus and tacrolimus are successfully used in both AD and ACD $[2,41]$.

\section{Other treatment methods}

An important aspect of treatment, apart from topical medications, is the use of non-pharmacological methods. climate therapy, psychological or psychi- le EASI oraz POEM są rekomendowane przez grupe HOME (Harmonising Outcome Measures for Eczema) do stosowania w badaniach klinicznych w celu ujednolicenia metod pomiaru nasilenia $\mathrm{AD}[42,43]$.

\section{LECZENIE}

Postępowanie terapeutyczne $\mathrm{w}$ AD i ACD zależy od stopnia nasilenia choroby. Niezbędne jest unikanie alergenów i czynników drażniących, co jest szczególnie ważne w ACD. Jeśli jest to niemożliwe, należy wdrożyć odpowiednie postępowanie. W zależności od fazy choroby należy modyfikować leczenie [2, 41].

\section{Leczenie miejscowe}

Kompleksowa terapia emolientowa ma na celu przywrócenie i naprawę zaburzonej funkcji bariery naskórkowej w AD. Emolienty aplikuje się zarówno w aktywnej fazie choroby, jak i w okresie remisji. Stosowane są one w celu nawilżenia skóry, przywracania szczelności warstwy rogowej naskórka, zmniejszenia świądu oraz hamowania wnikania haptenów. Istotne jest odpowiednio częste nakładanie ich na skórę (co najmniej 2-3 razy dziennie, 250-500 g/tydzień). Nie należy stosować emolientów bezpośrednio na skórę $\mathrm{z}$ aktywnym stanem zapalnym - w tym przypadku należy w pierwszej kolejności zastosować leki przeciwzapalne - miejscowo glikokortykosteroidy (mGKS) i miejscowo inhibitory kalcyneuryny (mIK) [39]. Mimo że rola emolientów w ACD nie jest tak kluczowa jak w AD, to należy zaznaczyć, że warto dodać je do standardowego postępowania. W ACD środki zmiękczające, nawilżające lub kremy ochronne mogą stanowić element profilaktyki wtórnej przed podrażnieniem [2].

Poza emolientami podstawą leczenia są mGKS, które ze względu na siłę działania zostały podzielone na grupy. Należy wspomnieć, że siła działania mGKS zależy od stężenia i postaci, w jakiej występuje [39]. W fazie przewlekłej AD zaleca się maści lub kremy zawierające 5-10\% mocznika i/lub 5-10\% kwasu salicylowego. Glikokortykosteroidy, oprócz działania przeciwzapalnego, antyproliferacyjnego i immunosupresyjnego, mają działanie przeciwświądowe. Dobre przenikanie do skóry wiąże się również z wystąpieniem działań niepożądanych. Stosuje się je również jako leczenie pierwszego wyboru w ACD. Glikokortykosteroidy o średniej lub dużej sile działania do stosowania miejscowego (np. $0,1 \%$ acetonidu triamcynolonu lub $0,05 \%$ propionian klobetazolu) mają zastosowanie w leczeniu ostrych zmian zlokalizowanych, natomiast na obszarach o cieńszej skórze (np. powierzchnie zgięciowe, powieki, skóra twarzy, okolicy odbytu i narządów płciowych) w celu zminimalizowania ryzyka atrofii zasadne jest stosowanie GKS o mniejszej mocy. Jeżeli 
atric help, phototherapy - especially UVB311, UVA1 and, in the case of adults, PUVA.

More severe forms of AD may require hospitalization, the use of strong immunosuppressants - such as oral GCS (with a maximum duration of therapy up to 7 days), cyclosporin A, methotrexate, mycophenolate mofetil or azathioprine.

In some cases refractory to conventional therapy, dupilumab, which is a fully human monoclonal antibody directed against the IL-4a receptor (IL-4R) that inhibits IL-4/IL-13 signaling, may be considered. The drug is registered in AD, asthma and adjuvant treatment of chronic rhinitis and sinusitis with polyps [41].

In $A C D$, the use of PUVA should also be considered [2].

\section{Antihistamines}

Antihistamines are often used to control itching as an adjunct to basic treatment. According to the selectivity of blocking histamine receptors, the following are distinguished: $1^{\text {st }}$ and $2^{\text {nd }}$ generation of histamine $\mathrm{H} 1$ receptor antagonists. Currently, the recommended first-generation antihistamine is hydroxyzine, which is used in allergic diseases accompanied by severe itching. First-generation drugs are non-selective, therefore they additionally block dopaminergic, cholinergic, serotoninergic and adrenergic receptors. Lack of selectivity is associated with adverse effects - drowsiness, hypotonia and impaired motor coordination. Therefore, these drugs are not recommended for routine use, especially in children [41]. Antihistamines help to reduce the symptoms of the acute phase of ACD [2].

\section{AVOIDING ALLERGIC CONTACT DERMATITIS SYMPTOMS-TRIGGERING FACTORS}

Hand protection is particularly important in the context of occupational hand dermatitis, which most often affects professions such as hairdressers, healthcare workers, food industry workers, metalworkers and bricklayers. It can result in the development of severe and chronic dermatitis. In most Western countries, occupational dermatitis of hands is the most common or at least the second most common occupational disease in recent years, affecting about 5 to 20 cases per 10,000 full-time employees per year, and in fact possibly even more due to low recognition and failure to report occupational diseases in fear of losing a job $[43,44]$.

\section{INTERFERENCE}

$\mathrm{AD}$ and contact allergic dermatitis share similarities in terms of clinical symptoms, morphology and zmiany skórne zajmują znaczną powierzchnię skóry (> 20\%), należy rozważyć stosowanie ogólnie GKS. Zaleca się podawanie prednizonu przez 5-7 dni w dawce $0,5-1 \mathrm{mg}$ na $\mathrm{kg}$ m.c./dobę, następnie stopniowo go odstawiając $[1,2]$.

Innym powszechnie stosowanym lekiem są mIK. Jest to grupa leków pozbawiona działań ubocznych, które obserwuje się przy stosowaniu mGKS. Preparaty te należą do leków o potwierdzonym działaniu przeciwzapalnym i przeciwalergicznym. Pimekrolimus i takrolimus są z powodzeniem stosowane zarówno w AD, jak i ACD $[2,41]$.

\section{Inne metody leczenia}

Ważnym aspektem leczenia poza lekami miejscowymi jest stosowanie metod niefarmakologicznych - wymienia się m.in. klimatoterapię, pomoc psychologiczną lub psychiatryczną, fototerapię - szczególnie UVB311, UVA1 i, w przypadku osób dorosłych, PUVA.

Cięższe postacie AD mogą wymagać hospitalizacji, stosowania ogólnie leków immunosupresyjnych: ogólnionych glikokortykosteroidów (o maksymalnym czasie trwania terapii do $7 \mathrm{dni}$ ), cyklosporyny, metotreksatu, mykofenolanu mofetylu lub azatiopryny.

W opornych na klasyczne leczenie przypadkach można zastosować dupilumab, który jest w pełni ludzkim przeciwciałem monoklonalnym skierowanym przeciwko receptorowi a IL-4 (IL-4R), hamującym przekazywanie sygnałów za pośrednictwem IL-4/IL-13. Lek ten posiada rejestrację w AD, astmie i leczeniu uzupełniającym przewlekłego zapalenia nosa i zatok przynosowych z polipami [41].

W ACD należy także rozważyć stosowanie PUVA [2].

\section{Leki przeciwhistaminowe}

Leki przeciwhistaminowe są często wykorzystywane w celu zniesienia świądu jako terapia uzupełniająca leczenie podstawowe. Ze względu na selektywność blokowania receptorów histaminowych wyróżnia się I oraz II generację antagonistów receptorów histaminowych H1. Obecnie z leków przeciwhistaminowych I generacji zaleca się głównie stosowanie hydroksyzyny, którą stosuje się w chorobach alergicznych z towarzyszącym dużym świądem. Leki I generacji są nieselektywne, w związku z czym blokują dodatkowo receptory dopaminergiczne, cholinergiczne, serotoninergiczne i adrenergiczne. Brak selektywności niesie ze sobą skutki uboczne - senność, hipotonię oraz zaburzenia koordynacji ruchowej. W związku z tym leki te nie są zalecane do rutynowego stosowania, szczególnie u dzieci [41]. Leki przeciwhistaminowe pomagają zmniejszyć objawy ostrej fazy ACD [2]. 
histology of eruptions, but their etiopathogenesis is different. However, the interference of immunological phenomena in the course of AD and ACD should be borne in mind. Disturbances in the course of $\mathrm{AD}$, concerning both the innate immune system (a defect of the skin-epidermal barrier) and the acquired immune response (participation of lymphocytes and their cytokines) are important in the pathomechanism of contact allergy. ACD is associated with a delayedtype immune reaction, and the response takes place in two phases - induction and symptomatic $[45,46]$. Both immunological factors related to type I and type IV allergic reactions, as well as non-allergic factors, are involved in the development of AD. The chronic nature of skin lesions in the course of $\mathrm{AD}$ is explained by presence of high-affinity IgE receptors (FceRI) on the surface of Langerhans cells, as well as the mechanism of IgE-dependent eczema, discovered by Bruijnzeel-Coomen [47]. In a study by Szepietowski et al., similar changes in expression of cytokines in the skin of both AD patients and non-atopy patients were observed after contact with nickel sulphate [48]. Szepietowski et al. showed that nickel sulphate caused an increase in mRNA expression for interleukin IL-2, IL-4 and IFN- $\gamma$ in patients with AD and ACD. Only in the case of IL-10 the increased expression was observed solely in people without AD. Both " $1^{\text {st }}$ type" (IFN- $\gamma$, IL-2 and IL-12) and " $2^{\text {nd }}$ type" (IL-4, IL-5 and IL-13) cytokines are involved in the pathomechanism of ACD. Dominance of a given type of lymphocytes, and hence of secreted cytokines, is related to properties of a contact allergen, as well as the duration of the inflammatory process. The dominance of Th1 lymphocytes takes place during sensitization to dinitrofluorobenzene (DNFB), and of Th2 lymphocytes in the case of fluorescein isothiocyanate (FITC), while methylchloroisothiazolinone/methylisothiazolinone (MCI/MI) and metal salts engage both Th1 and Th2 lymphocytes [49]. An increase in the concentration of cytokines produced by Th2 occurs in the acute phase of atopic dermatitis, while Th1 - in the chronic phase [45]. Treg cells exert an inhibitory effect on helper lymphocytes, much stronger in Th1 than Th2 [50]. On the other hand, authors of other studies have even demonstrated the stimulating effect of Treg on Th2 lymphocytes [51]. Increased ICE activity and increased expression of VCAM-1 endothelial cell adhesion molecules enhance the phenomenon of delayed type hypersensitivity in the course of $\mathrm{AD}$ [52].

\section{CONCLUSIONS}

Atopic dermatitis and allergic contact eczema are two different nosological entities, clinical presentation and methods of diagnosis and treatment of

\section{UNIKANIE CZYNNIKÓW WYWOŁUJĄCYCH OBJAWY_ALERGICZNEGO WYPRYSKU KONTAKTOWEGO}

Ochrona rąk jest szczególnie istotna w wyprysku kontaktowym na tle zawodowym, które dotyczy najczęściej zawodów, takich jak fryzjerzy, pracownicy ochrony zdrowia, pracownicy przemysłu spożywczego, metalowcy i murarze. Jego następstwem może być rozwój ciężkiego i przewlekłego zapalenia skóry. W większości krajów zachodnich zawodowe zapalenie skóry rąk jest najczęstszą lub drugą w kolejności chorobą zawodową. W ostatnich latach dotyczy około 5 do 20 przypadków na 10000 pełnoetatowych pracowników rocznie, a w rzeczywistości prawdopodobnie jeszcze większej liczby osób z powodu niskiej rozpoznawalności i niezgłaszania chorób zawodowych w obawie przed utratą pracy $[43,44]$.

\section{INTERFERENCJA}

Atopowe zapalenie skóry oraz kontaktowe alergiczne zapalenie skóry łączą podobieństwa w zakresie objawów klinicznych, obrazu morfologicznego i histologicznego wykwitów, natomiast różna jest ich etiopatogeneza. Należy jednak pamiętać o interferencji zjawisk immunologicznych w przebiegu AD i ACD. Zaburzenia w przebiegu AD dotyczące układu odpornościowego wrodzonego (defekt bariery skórno-naskórkowej) oraz nabytej odpowiedzi immunologicznej (udział limfocytów i wydzielanych przez nie cytokin) mają istotne znaczenie w patomechanizmie alergii kontaktowej. ACD związany jest z reakcją immunologiczną typu opóźnionego, a odpowiedź przebiega w dwóch fazach - indukcji oraz ujawniania $[45,46]$. W powstawaniu AD biorą udział zarówno czynniki immunologiczne związane z I, jak i IV typem reakcji alergicznej, a także czynniki niealergiczne. Przewlekły charakter zmian skórnych w przebiegu AD wyjaśnia obecność odkrytych przez Bruijnzeel-Coomen receptorów dla immunoglobuliny IgE o wysokim powinowactwie (FceRI) na powierzchni komórek Langerhansa, a także mechanizm wyprysku IgE-zależnego [47]. W badaniu Szepietowskiego i wsp. zaobserwowano podobne zmiany ekspresji cytokin w skórze zarówno pacjentów chorych na $\mathrm{AD}$, jak i osób bez cech atopii po kontakcie z siarczanem niklu [48]. Szepietowski i wsp. wykazali, że siarczan niklu wywołał wzrost ekspresji mRNA dla interleukiny IL-2, IL-4 oraz IFN- $\gamma$ u pacjentów z AD i ACD, jedynie w przypadku IL-10 zwiększona ekspresja dotyczyła tylko osób bez $\mathrm{AD}$. W patomechanizmie ACD biorą udział cytokiny zarówno „1. typu” (IFN- $\gamma$, IL-2 oraz IL-12), jak i „2. typu” (IL-4, IL-5 oraz IL-13). Przewaga danego typu limfocytów oraz wydzielanych cytokin ma związek z właściwościami alergenu kontaktowego, a także z czasem trwania procesu zapalnego. Dominacja limfocytów Th1 następuje podczas uczulenia na dinitrofluorobenzen (DNFB), przewaga limfocytów 
which overlap. However, they differ in important details - mainly regarding preferences of the beginning of therapy. In AD, more emphasis is placed on restoring the dysfunctional epidermal barrier, and in allergic contact dermatitis, avoiding a potential triggering factor. In the group of patients, the so-called interference, that is, overlapping symptoms of both dermatoses is common, but exact mechanisms underlying these phenomena are still under investigation.

\section{CONFLICT OF INTEREST}

The authors declare no conflict of interest.
Th2 w przypadku izotiocyjanianu fluoresceiny (FITC), natomiast metylochloroizotiazolinon/metylizotiazolinon (MCI/MI) oraz sole metali angażują limfocyty zarówno Th1, jak i Th2 [49]. Wzrost stężenia cytokin produkowanych przez Th2 zachodzi w ostrej fazie wyprysku atopowego, natomiast Th1 - w fazie przewlekłej [45]. Komórki Treg wywołują efekt hamujący w przypadku limfocytów pomocniczych, dużo mocniej w zakresie Th1 niż Th2 [50]. Autorzy innych badań wykazali nawet pobudzający wpływ Treg na limfocyty Th2 [51]. Zwiększona aktywność oraz wzrost ekspresji cząsteczek ICAM-1 (intercellular adhesion molecule 1) i VCAM-1 (vascular cell adhesion protien 1) na komórkach śródbłonka wzmagają zjawisko nadwrażliwości typu opóźnionego w przebiegu AD [52].

\section{PODSUMOWANIE}

Atopowe zapalenie skóry i alergiczny wyprysk kontaktowy to dwie różne jednostki nozologiczne, których zarówno obraz kliniczny, jak i metody diagnostyki oraz leczenia mają niektóre wspólne elementy; różnią się natomiast $\mathrm{w}$ istotnych szczegółach. W AD bardzo istotna jest odbudowa dysfunkcyjnej bariery naskórkowej, a w ACD unikanie potencjalnego czynnika wyzwalającego. U chorych często występuje nakładanie się objawów jednej i drugiej dermatozy, jednak dokładne mechanizmy leżące u podstawy tych zjawisk wciąż są badane.

\section{KONFLIKT INTERESÓW}

Autorzy nie zgłaszają konfliktu interesów.

\section{References}

\section{Piśmiennictwo}

1. Bartoszak L.: Alergia kontaktowa u dzieci i młodzieży chorych na atopowe zapalenie skóry. Uniwersytet Medyczny w Poznaniu, Poznań, 2011.

2. Murphy P.B., Atwater A.R., Mueller M.: Allergic contact dermatitis. StatPearls [Internet]. Treasure Island (FL): StatPearls Publishing 2021.

3. Ring J.: 1st description of an "atopic family anamnesis" in the Julio-Claudian imperial house: Augustus, Claudius, Britannicus. Hautarzt 1985, 36, 470-471.

4. Polańska A., Jenerowicz D.: Rys historyczny wybranych zagadnień związanych z etiopatogenezą i leczeniem atopowego zapalenia skóry. Nowiny Lekarskie 2008, 77, 382-384.

5. Hanifin J.M., Rajka G.: Diagnostic features of atopic dermatitis. Acta Derm Venereol Suppl 1980, 92, 44-47

6. Marciniak A., Hasse-Cieślińska M., Jenerowicz D., Czarnecka-Operacz M.: The role of minor Hanifin and Rajka criteria in diagnosis of atopic dermatitis patients. Adv Dermatol Allergol 2008, 25, 55-60.

7. Hjorth N.: History of contact dermatitis and its influence on today's occupational dermatology. Hautarzt 1980, 31, 621-626.

8. de Guzman Strong C., Conlan S., Deming C.B., Cheng J., Sears K.E., Segre J.A.: A milieu of regulatory elements in the epidermal differentiation complex syntenic block: implications for atopic dermatitis and psoriasis. Hum Mol Genet 2010, 19, 1453-1460.

9. Elias P.M., Wakefield J.S.: Mechanisms of abnormal lamellar body secretion and the dysfunctional skin barrier in patients with atopic dermatitis. J Allergy Clin Immunol 2014, 134, 781-791.

10. Chan A., Mauro T.: Acidification in the epidermis and the role of secretory phospholipases. Dermatoendocrinology 2011, 3 , 84-90.

11. Boguniewicz M., Leung D.Y.M.: Atopic dermatitis. [In:] Middleton's Alergy: Principles and Practice. R.L. Nixon, T. Diepge (eds.). Elsevier, Philadelphia 2014, 540-564.

12. Grize L., Gassner M., Wüthrich B., Bringolf-Isler B.: Trends in prevalence of asthma, allergic rhinitis and atopic dermatitis in 5-7year old Swiss children from 1992 to 2001 . Allergy 2006, 61, 556-562

13. Weber A.S., Haidinger G.: The prevalence of atopic dermatitis in children is influenced by their parents' education: results of two cross-sectional studies conducted in Upper Austria. Pediatr Allergy Immunol 2010, 21, 1028-1035. 
14. Kowalska-Oledzka E., Czarnecka M., Baran A.: Epidemiology of atopic dermatitis in Europe. J Drug Assessment 2019, 8, $126-128$.

15. Peiser M., Tralau T., Heidler J., Api A.M., Arts J.H.E., Basketter D.A.: Allergic contact dermatitis: epidemiology, molecular mechanisms, in vitro methods and regulatory aspects. Cell Mol Life Sci 2012, 69, 763-781.

16. Bacharewicz-Szczerbicka J., Reduta T., Pawłoś A., Flisiak I.: Ocena wyników testów naskórkowych u dzieci i młodzieży z alergicznym wypryskiem kontaktowym - porównanie grup pacjentów z atopowym zapaleniem skóry i bez atopowego zapalenia skóry. Dermatol Rev 2017, 104, 77-91.

17. Nowicki R.: Leczenie infekcji skóry w atopowym zapaleniu skóry. Forum Medycyny Rodzinnej 2010, 4, 323-329.

18. Silvestre-Salvador J.F., Romero-Pérez D., Encabo-Durán B.: Atopic dermatitis in adults: a diagnostic challenge. J Investig Allergol Clin Immunol 2017, 27, 78-88.

19. Williams H.C.: Atopic dermatitis. N Engl J Med 2005, 352, 2314-2324.

20. Bieber T., D’Erme A.M., Akdis C.A., Traidl-Hoffmann C., Lauener R., Schäppi G., et al.: Clinical phenotypes and endophenotypes of atopic dermatitis: where are we, and where should we go? J Allergy Clin Immunol 2017, 139, 58-64.

21. Marrero-Alemán G., Sabater-Abad J., Miquel F.J., Boix-Vilanova J., Mestre Bauzá F., Borrego L.: Allergic contact dermatitis to (meth)acrylates involving nail technicians and users: prognosis and differential diagnosis. Allergy 2019, 74, 1386-1389.

22. Gonçalo M., Pinho A., Agner T., Andersen K.E., Bruze M., Diepgen T., et al.: Allergic contact dermatitis caused by nail acrylates in Europe. An EECDRG study. Contact Dermatitis 2018, 78, 254-260.

23. DeKoven S., DeKoven J., Holness D.L.: (Meth)acrylate occupational contact dermatitis in nail salon workers: a case series. J Cutan Med Surg 2017, 21, 340-344.

24. Kieć-Świerczyńska M., Kręcisz B., Chomiczewska-Skóra D.: Occupational contact dermatitis to acrylates in a manicurist. Occup Med 2013, 63, 380-382.

25. Nassau S., Fonacier L.: Allergic contact dermatitis. Med Clin North Am 2020, 104, $61-76$

26. Eichenfield L.F., Tom W.L., Berger T.G., Krol A., Paller A.S., Schwarzenberger K., et al.: Guidelines of care for the management of atopic dermatitis: section 2. Management and treatment of atopic dermatitis with topical therapies. J Am Acad Dermatol 2014, 70, 338-351.

27. Epps R.E.: Atopic dermatitis and ichthyosis. Pediatr Rev 2010, 31, 278-285.

28. Thyssen J.P., Godoy-Gijon E., Elias P.M.: Ichthyosis vulgaris: the filaggrin mutation disease. Br J Dermatol 2013, 168, 1155-1166.

29. Gruber R., Sugarman J.L., Crumrine D., Hupe M., Mauro T.M., Mauldin E.A., et al.: Sebaceous gland, hair shaft, and epidermal barrier abnormalities in keratosis pilaris with and without filaggrin deficiency. Am J Pathol 2015, 185, 1012-1021.

30. Rystedt I.: Atopic background in patients with occupational hand eczema. Contact Dermat 1985, 12, 247-254.

31. Ibler K.S., Jemec G.B., Flyvholm M.A., Diepgen T.L., Jensen A., Agner T.: Hand eczema: prevalence and risk factors of hand eczema in a population of 2274 healthcare workers. Contact Dermatitis 2012, 67, 200-207.

32. Langan S.M., Abuabara K., Henrickson S.E., Hoffstad O., Margolis D.J.: Increased risk of cutaneous and systemic infections in atopic dermatitis-a cohort study. J Invest Dermatol 2017, 137, 1375-1377.

33. Bauer A., Seidel A., Bartsch R., Wollina U., Gebhardt M., Diepgen T.L.: Development of skin damage during vocational training in occupations with skin hazards [Entwicklung von Hautproblemen bei Berufsanfängern in Hautrisikoberufen]. Allergologie 1997, 20, 179-183.

34. Coenraads P.J., Diepgren T.L.: Risk for hand eczema for employees with past or present atopic dermatitis. Int Arch Occup Environ Health 1998, 71, 7-13.

35. Ong P.Y., Leung D.Y.: Bacterial and viral infections in atopic dermatitis: a comprehensive review. Clin Rev Allergy Immunol 2016, 51, 329-337.

36. Glatz M., Bosshard P., Schmid-Grendelmeier P.: The role of fungi in atopic dermatitis. Immunol Allergy Clin N Am 2017, 37, 63-74.

37. Andersen Y.M., Egeberg A., Gislason G.H., Skov L., Thyssen J.P.: Autoimmune diseases in adults with atopic dermatitis. J Am Acad Dermatol 2017, 76, 274-280.

38. Williams H.C., Burney P.G., Pembroke A.C., Hay R.J.: The U.K. Working Party's Diagnostic Criteria for Atopic Dermatitis. III. Independent hospital validation. Br J Dermatol 1994, 131, 406-416.

39. Kang K.F., Tian R.M.: Criteria for atopic dermatitis in a Chinese population. Acta Derm Venereol Suppl 1989, 44, $26-27$.

40. Lee S.C.: Various diagnostic criteria for atopic dermatitis (AD): A proposal of Reliable Estimation of Atopic Dermatitis in Childhood $(\mathrm{REACH})$ criteria, a novel questionnaire-based diagnostic tool for AD. Japanese Dermatological Association. J Dermatol 2016, 43, 376-384.

41. Nowicki R.J., Trzeciak M., Kaczmarski M., Wilkowska A., Czarnecka-Operacz M., Kowalewski C., et al.: Atopowe zapalenie skóry. Interdyscyplinarne rekomendacje diagnostyczno-terapeutyczne Polskiego Towarzystwa Dermatologicznego, Polskiego Towarzystwa Alergologicznego, Polskiego Towarzystwa Pediatrycznego oraz Polskiego Towarzystwa Medycyny Rodzinnej. Część I. Profilaktyka, leczenie miejscowe i fototerapia. Dermatol Rev 2019, 106, 354-371.

42. Bożek A., Reich A.: Metody oceny nasilenia atopowego zapalenia skóry. Przegl Dermatol 2016, 103, 479-485.

43. Yang Y.B., Lynde C.W., Fleming P.: Common atopic dermatitis rating scales: a practical approach and brief review. J Cutaneous Med Surg 2020, 24, 399-404.

44. Bauer A., Rönsch H., Elsner P., Dittmar D., Bennett C., Schuttelaar M.L.A., et al.: Interventions for preventing occupational irritant hand dermatitis. Cochrane Database Syst Rev 2018, 30, CD004414.

45. Gliński W.: Atopic dermatitis: pathogenesis and treatment - international principle. Pneumonol Alergol Pol 2002, 70, 39-40.

46. Saint-Mezard P., Rosieres A., Krasteva M., Berard F., Dubois B., Kaiserlian D., et al.: Allergic contact dermatitis. Eur J Dermatol 2004, 14, 284-95.

47. Bruynzeel-Koomen C., van der Donk E.M., Bruynzeel P.L., Capron M., de Gast G.C., Mudde G.C.L.: Associated expression of CD1 antigen and Fc receptor for IgE on epidermal Langerhans cells from patients with atopic dermatitis. Clin Exp Immunol 1988, $74,137-142$. 
48. Szepietowski J.C., McKenzie R.C., Keohane S.G., Aldridge R.D., Hunter J.A.A.: Atopic and non-atopic individuals react to nickel challenge in a similar way. A study of the cytokine profile in nickel-induced contact dermatitis. Br J Dermatol 1997, 317, 195-200.

49. Masjedi K., Ahlborg N., Gruvberger B., Bruze M., Karlberg A.T.: Methylisothiazolinones elicit increased production of both T helper (Th)1- and Th2-like cytokines by peripheral blood mononuclear cells from contact allergic individuals. Br J Dermatol 2003, $149,1172-1182$

50. Ou L.S., Goleva E., Hall C., Leung D.Y.M.: T regulatory cells in atopic dermatitis and subversion of their activity by superantigens. J Allergy Clin Immunol 2004, 113, 756-763.

51. Suto A., Nakajima H., Kagami S.I., Suzuki K., Saito Y., Iwamoto I.: Role of CD4(+) CD25(+) regulatory T cells in T helper 2 cell-mediated allergic inflammation in the airways. Am J Respir Crit Care Med 2001, 164, 680-687.

52. Chen L., Lin S., Amin S., Overbergh L., Maggiolino G., Chan L.S.: VCAM-1 blockade delays disease onset, reduces disease severity and inflammatory cells in an atopic dermatitis model. Immunol Cell Biol 2010, 88, 334-342.

Received: 22.07 .2021

Accepted: 25.10.2021

Otrzymano: $22.07 .2021 \mathrm{r}$.

Zaakceptowano: $25.10 .2021 \mathrm{r}$.

How to cite this article

Kanabaj K., Shawkat S., Kuźniak A., Adamski Z., Jenerowicz D.: Selected clinical and therapeutic aspects of atopic and contact dermatitis. Dermatol Rev/Przegl Dermatol 2021, 108, 394-406. DOI: https://doi.org/10.5114/dr.2021.113157 